\title{
Aplikasi Berbasis Dekstop Untuk Persediaan Bahan Baku Produksi Menggunakan Model Waterfall (Study Kasus: PT. Seyon Indonesia)
}

\author{
Eka Chandra Ramdhani ${ }^{* *}$, Hotniasi Gaja ${ }^{2}$, Ratnawati ${ }^{3}$ \\ ${ }^{1}$ Jurusan Manajemen Informatika, AMIK BSI Bekasi \\ ${ }^{2}$ Jurusan Manajemen Informatika, AMIK BSI Karawang \\ ${ }^{3}$ Jurusan Manajemen Informatika, AMIK BSI Tegal \\ ${ }^{1} \mathrm{Jl}$. Cut Meutia No. 88, Kota Bekasi, Jawa Barat, 17111, Indonesia \\ ${ }^{2} J$ In. Ir. Juanda No. 17 Kota Baru Cikampek, Kab Karawang, 41374, Indonesia \\ ${ }^{3} \mathrm{~J}$ In Sipelem No.2, Tegal Barat, Tegal, Indonesia \\ email: ${ }^{1}$ eka.ecr@bsi.ac.id, ${ }^{2}$ hotniasi.gaja @ gmail.com, ${ }^{3}$ ratnawati.rtx @ bsi.ac.id
}

Received: 26 Maret 2018; Revised:15 Mei 2018; Accepted: 15 Mei 2018

Copyright @2018 Politeknik Harapan Bersama Tegal. All rights reserved

\begin{abstract}
Basically the computer functions are generally used as a medium for storing data and in it there are many application programs that can simplify and support a human work. In the warehouse of PT Seyon Indonesia for the process of inventory data management (raw and supporting), reports and data storage is still done manually. The existence of data recording errors and data inaccuracies are very likely to occur in this regard. To help facilitate the management of inventory data (raw and supporting) in the section, the design of the program is the best solution to solve the problems that exist, namely in terms of data processing more accurate because the availability of input form data available and storage media centered in a single database that will make data management of incoming and outgoing goods more effective and efficient. The design of the inventory program (raw and supporting) is made with a simple and interactive appearance but can process data well, so users can easily use it.
\end{abstract}

Abstrak - Pada dasarnya fungsi komputer umumnya digunakan sebagai media untuk menyimpan data dan didalamnya terdapat banyak program aplikasi yang dapat mempermudah serta menunjang suatu pekerjaan manusia. Pada bagian gudang PT Seyon Indonesia untuk proses pengelolaan data persediaan barang (baku dan pendukung), laporan-laporan dan penyimpanan data masih dilakukan secara manual. Adanya kesalahan pencatatan data serta ketidakakuratan data sangat mungkin terjadi dalam hal ini. Untuk membantu mempermudah dalam pengelolaan data persediaan barang (baku dan pendukung) pada bagian tersebut, aplikasi berbasis dekstop merupakan solusi yang terbaik untuk memecahkan permasalahan-permasalahan yang ada, yaitu dari segi pengolahan data yang lebih akurat karena tersedianya form penginputan data yang tersedia dan media penyimpanan yang terpusat dalam satu database yang akan membuat pengelolaan data barang

*) Corresponding author: Eka Chandra Ramdhani

Email: eka.ecr@bsi.ac.id masuk dan keluar lebih efektif dan efisien. aplikasi persediaan barang (baku dan pendukung) ini dibuat dengan tampilan yang sederhana dan interaktif namun dapat mengolah data dengan baik, sehingga pengguna dapat dengan mudah menggunakannya.

Kata Kunci - Data, Inventory Management, Raw and Support

\section{PENDAHULUAN}

Abad ke-21 merupakan abad serba komputer dimana hampir semua bidang kegiatan manusia menggunakan komputer. Dengan komputer banyak kemudahan-kemudahan yang dapat kita peroleh. Salah satunya kemudahan dari segi pengolahan data. Saat ini pun banyak perusahaan yang sudah menggunakan komputer dalam pengolahan data perusahaan. Bahkan beberapa dari mereka saling bersaing untuk mengembangkan dan menciptakan satu aplikasi untuk diterapkan di perusahaannya terutama dalam bidang pengelolaan data dan pengembangan sistem data.

Penggunaan komputer ini dapat dilakukan secara rutin untuk tugas-tugas penting yang menyangkut data dalam jumlah besar. Kegunaan komputer akan semakin meningkat salah satunya sebagai alat pendukung dalam pengambilan keputusan, sehingga dapat mengatasi masalah yang terjadi dalam sebuah perusahaan.

PT Seyon Indonesia merupakan sebuah perusahaan garmen sarung tangan yang hasil produksinya di ekspor ke beberapa negara seperti Amerika, Australia, Jepang, Korea dan sebagainya. Untuk jenis produk yang dihasilkan berupa sarung tangan ski, golf, sarung tangan pada saat musim dingin (salju) dan sarung tangan sepeda motor dengan bermacammacam merk untuk segala usia dan jenis kelamin. Di PT Seyon Indonesia tidak hanya ada bagian menjahit saja namun tersedia pula bagian untuk pencetakan logo, sarung tangan pelindung dan bordir. PT Seyon Indonesia juga sering melakukan kerja sama dalam memproduksi sarung tangannya dengan perusahaan garmen lain baik dalam propinsi maupun luar propinsi. PT Seyon Indonesia saat ini mampu 
memproduksi sarung tangan rata-rata 1.500 .000 pasang pertahunnya.

Pada sistem pengolahan data pada PT Seyon Indonesia sebenarnya hampir setiap bagian atau departemen sudah terkomputerisasi. Namun sistem pengolahan data persediaan bahan baku dan pendukung pada bagian inventory masih dilakukan secara konvensional yaitu pencatatan menggunakan media buku. Sering terjadi kesalahan dalam pemasukan data dan jumlah stok barang. Persediaan barang yang terlalu besar tentunya akan mengakibatkan kerugian bagi perusahaan begitu pula sebaliknya, kekurangan persediaan akan mengakibatkan terhambatnya pekerjaan khususnya di bagian produksi, ditambah permasalahan dari segi pencarian data yang sulit serta laporan transaksi yang kurang terpantau. Pada saat pembuatan laporan pun memerlukan waktu yang lebih lama karena laporan dibuat secara manual (beberapa kali perekapan data).

Tujuan utama dari pembangunan aplikasi persediaan bahan baku berbasis desktop ini adalah sebagai pengganti sistem konvensional yang masih digunakan oleh perusahaan sehingga diharapkan dengan adanya aplikasi ini akan meminimalisir kesalahan ketika melakukan pemrosesan data dan akhirnya akan mempercepat proses pengolahan dan pengelolaan data pada PT. Seyon Indonesia dengan efektif dan efisien.

Model yang digunakan adalah metode waterfall, metode ini merupakan metode pengambangan software yang banyak dirujuk, karena model ini memiliki tahapan terurut dalam penggunaannya. Tahapan metode ini yakni menganalisa kebutuhan pengguna terhadap software, mendesain software, menuliskan kode program, melakukan pengujian, menerapkan dan melakukan pemeliharaan software tersebut. Dengan tahapan tersebut, maka secara signifikan akan dapat mengurangi adanya ketidakpuasan dari pengguna karena kebutuhan akan software telah diketahui dengan jelas, oleh karena itu penulis mengadopsi metode ini sebagai metode pengembangan perangkat lunak persediaan bahan baku agar dapat menggantikan sistem konvensional yang masih digunakan saat ini.

\section{PENELITIAN YANG TERKAIT}

Penelitian terkait dengan program (aplikasi) persediaan bahan baku telah diteliti dan dikembangkan oleh para peneliti sebelumnya dengan berbagai metode yang digunakan. Menurut Yudhi Yanuar dkk., (2016) [14] meneliti, mendesain dan membangun pengelolaan bahan baku dengan aplikasi berbasis web dan metode yang digunakan adalah metode Economic Order Quantity yang dapat digunakan untuk mengatasi pengelolaan bahan baku yang berlebihan. Aplikasi ini dapat mengelola master data, pembelian bahan baku, pengelolaan bahan baku produksi, perhitungan biaya pemesanan bahan baku, menghasilkan laporan pembelian bahan baku, laporan produksi, jurnal dan buku besar. Perusahaan dapat menggunakan aplikasi ini untuk mengelola bahan baku produksi dengan perhitungan Economic Order Quantity.

Penelitian yang lain meurut Reza Abdurrofi dkk., (2016) [10] menggunakan Persediaan dapat dikendalikan dengan Model Economic Order Quantity (EOQ) agar dapat menghasilkan perhitungan jumlah pesanan ekonomis dengan biaya seminimal mungkin. Aplikasi dibuat berbasis web dengan fungsionalitas menghitung EOQ untuk mengendalikan jumlah bahan baku dari proses persediaan dengan Model EOQ dengan mempertimbangkan Safety stock dan reorder point, serta menyajikan laporan akuntansi dalam bentuk jurnal, buku besar, laporan pembelian dan laporan data produksi.

Penelitian berikutnya dari Rianti Rahmawati dkk., (2016) [11] menerapkan kembali metode EOQ, perusahaan dapat menghitung jumlah pemesanan optimal sehingga mengurangi biaya pemesanan dan penyimpanan. Perusahaan juga dapat mengetahui jumlah persediaan pengaman (safety stock) dan kapan harus melakukan pemesanan kembali (reorder point). Selain itu, aplikasi ini mencatat setiap transaksi yang terjadi dalam perusahaan, dengan menggunakan aplikasi web.

Perbedaan dengan penelitian sebelumnya adalah penelitian sebelumnya membahas tentang pengelolaan bahan baku dengan menggunakan aplikasi berbasis web tetapi dalam penelitian ini dengan menggunakan aplikasi bebasis desktop kemudian persamaan dengan penelitian sebelumnya adalah dibangunnya aplikasi yang bertujuan untuk mengelola dan mengolah semua data dalam pengelolaan data bahan baku dalam sebuah perusahaan.

\section{METODE PENELITIAN}

\section{A. Kerangka Pemikiran}

Pada Gbr. 1 menggambarkan alur dari penelitian yang sudah dilaksanakan.

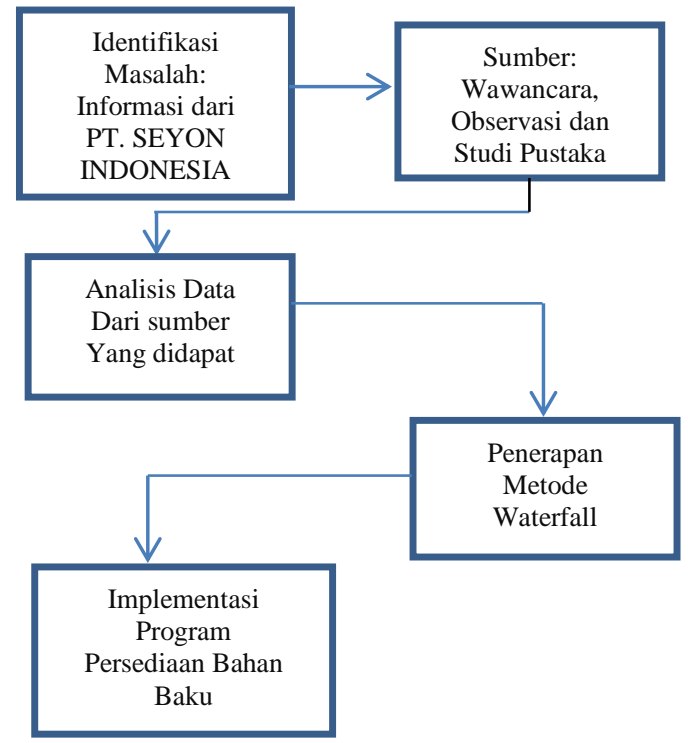

Gbr 1. Kerangka Pemikiran

\section{B. Bahan Penelitian}

Data yang diperlukan dalam melaksanakan dan mengimplementasikan penelitian ini meliputi data-data yang berhubungan dengan data persediaan bahan baku di PT. Seyon Indonesia. Data-data tersebut dihasilkan dari observasi langsung dan melakukan wawancara dengan orang-orang yang berkaitan.

\section{Alat Penelitian}

Alat yang digunakan untuk menggambarkan desain aplikasi persediaan bahan baku produksi yaitu menggunakan 
ERD dan LRS sebagai alat untuk merancang data base kemudian menggunakan flowchart dan HIPO untuk merancang alur dari program.

\section{Metode Pengembangan Perangkat Lunak}

Dalam pengembangan perangkat lunak ini menggunakan metode waterfall, yang mempunyai tahapan sebagai berikut [1]:

1) Requirements analysis and definition: Tahapan ini dapat dilakukan dengan menganalisis data dan dokumen yang berhubungan dengan persediaan dan juga diskusi langsung kepada pengguna mengenai kebutuhan akan sistem informasi yang akan dibuat sehingga menghasilkan konsep dan spesifikasi sistem yang sesuai dengan kebutuhan.

2) System and software design: Tahapan ini dilakukan dengan menentukan struktur data yang diperlukan, arsitektur perangkat lunak, dan desain antarmuka pengguna yang disesuaikan dengan konsep pada tahap analisis kebutuhan.

3) Implementation and unit testing: Proses implementasi ini adalah lanjutan dari tahap desain yang mengubah konsep dan rancangan arsitektur perangkat lunak menjadi sebuah program secara utuh, kemudian dilakukan pengujian terhadap program yang sudah dibuat agar program yang dibuat sesuai dengan konsep yang sudah ditetapkan pada awal proses.

4) Integration and system testing: Tahapan ini dibuat untuk menyatukan semua rancangan program menjadi sebuah kesatuan yang terintegritas serta dilakukan kembali verifikasi terhadap program utuh untuk disesuaikan dengan kebutuhan pengguna.

5) Operation and maintenance: Tahapan ini adalah tahapan penerapan aplikasi yang telah dirancang langsung kepada mengguna, dan apabila ditemukan kesalahan pada program, maka akan dilakukan penanganan error tersebut.

\section{E. Teknik pengumpulan data}

Metode pengumpulan data yang penulis laksanakan yaitu:

1) Observasi: Penulis mengadakan observasi secara langsung ke PT Seyon Indonesia, guna meneliti dan menganalisa permasalahan yang terjadi pada bagian persediaan atau gudang. Hal ini dilakuakan untuk mengidentifikasi aspek-aspek didalamnya dan mencatat kemudian melakukan pengembangan.

2) Wawancara: Penulis melakukan wawancara untuk memperoleh informasi dan data secara objektif, serta untuk mengetahui beberapa permasalahan yang di hadapi oleh pihak yang terkait dalam pengoperasian persediaan barang secara manual. Penulis mengajukan beberapa pertanyaan kepada kepala gudang yang bernama Bapak Roni Komala mengenai prosedur pencatatan data, pencarian data serta pembuatan laporan kepada manager/direktur di perusahaan. Sehingga akhirnya dijadikan bahan untuk penelitian ini.

3) Studi pustaka: Penulis mengumpulkan informasi melalui referensi dari beberapa buku, makalah, jurnal serta informasi dari internet atau website yang berkaitan dengan perancangan aplikasi berbasis desktop yang dapat menunjang.

\section{HASIL DAN PEMBAHASAN}

Dalam perancangan sebuah aplikasi perlu dilakukan proses analisa kebutuhan yang bertujuan untuk mencari dan menganalisa data tentang kebutuhan yang diperlukan pada sistem yang berjalan apakah masih terdapat kukarangan atau masalah yang dihadapi. Karena itu harus terdapat solusi yang dapat mengurangi ataupun menutup kekurangan dan masalah dari sistem yang telah ada. Analisa kebutuhan yang diperlukan terbagi menjadi dua bagian, antara lain:

\section{A. Kebutuhan Pengguna (User)}

Kebutuhan pengguna (user) merupakan aspek-aspek yang diperlukan pengguna (user) untuk menjalakan sistem sesuai dengan kriteria yang butuhkan untuk mempermudah pekerjaan pengguna. Adapun kebutuhan pengguna yang diperlukan adalah:

- User dapat mengelola akun user admin jika mempunyai hak akses sebagai admin.

- User dapat mengelola data barang seperti menambah, mengedit, menghapus data barang.

- User dapat mengelola data pemasok seperti menambah, mengedit, menghapus data pemasok.

- User dapat mengelola data supplier seperti menambah, mengedit, menghapus data supplier.

- User dapat menginput data transaksi barang masuk dan keluar.

- User dapat melihat data barang, pemasok, supplier, dan transaksi yang telah tersimpan didalam database.

- User dapat merubah password.

\section{B. Kebutuhan Sistem}

Kebutuhan sistem merupakan kemampuan, syarat atau kriteria yang harus ada atau dipenuhi oleh sistem, sehingga apa yang di inginkan pengguna (user) dari sistem dapat diwujudkan. Adapun kebutuhan sistem yang diperlukan adalah:

- Sistem dapat menampilkan data barang, data pemasok dan data supplier.

- Sistem dapat membuat bukti keluar barang.

- Sistem dapat mencetak laporan transaksi barang masuk dan keluar secara perhari, perminggu dan perbulan.

- Sistem dapat mencetak laporan data barang, data pemasok dan data supplier.

\section{Perancangan Sistem}

1) ERD (Entity Relationship Diagram)

Merupakan teknik yang digunakan untuk memodelkan kebutuhan data dari suatu organisasi [2]. 


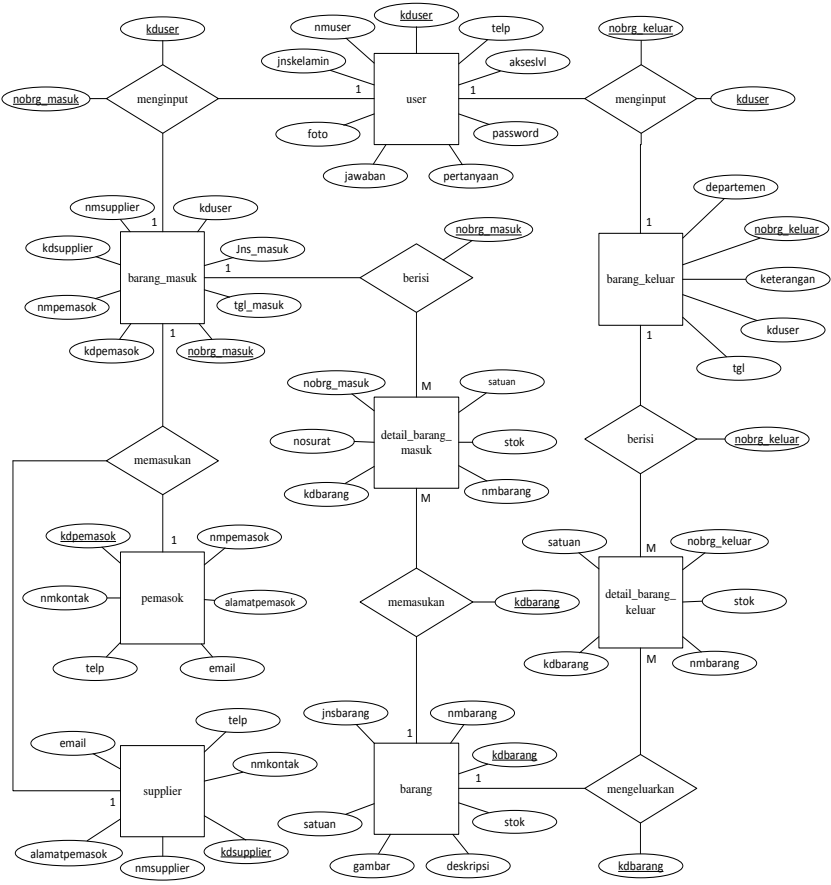

Gbr 2. ERD (Entity Relationship Diagram)

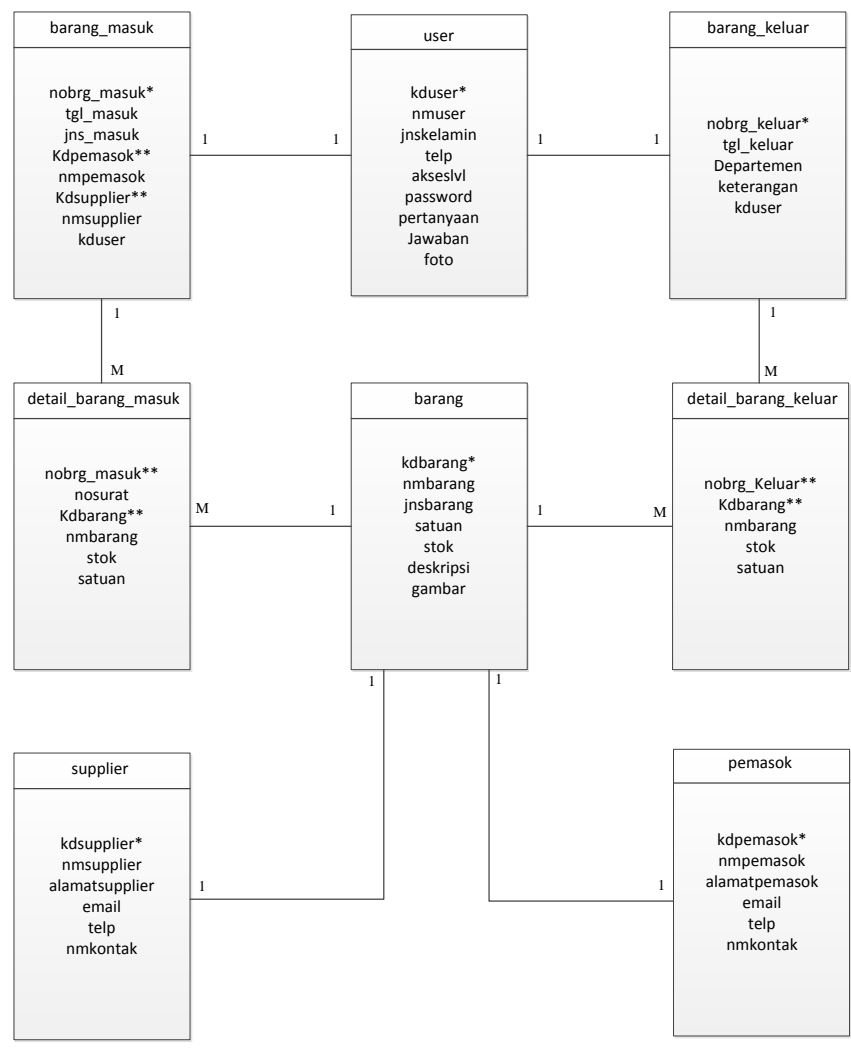

Gbr 3. LRS (Logical Record Structure)

ERD merupakan rancangan secara logika dari basis data yang akan digunakan. Pada Gbr 2. basis data yang dirancang terdiri dari 8 entitas yang saling berelasi.

\section{2) LRS (Logical Record Structure)}

Logical record structure terdiri dari link-link diantara tipe record. link ini menunjukan dari satu tipe record [13]. Pada Gbr 3. adalah gambaran LRS yang merupakan representasi dari ERD dalam bentuk tabel.

\section{3) HIPO (Hierarchy plus Input Process Output)}

Untuk menyediakan penjelasan yang jelas dari input yang harus digunakan dan output yang harus dihasilkan oleh masing-masing fungsi pada tiap-tiap tingkatan dari diagramdiagram [5].

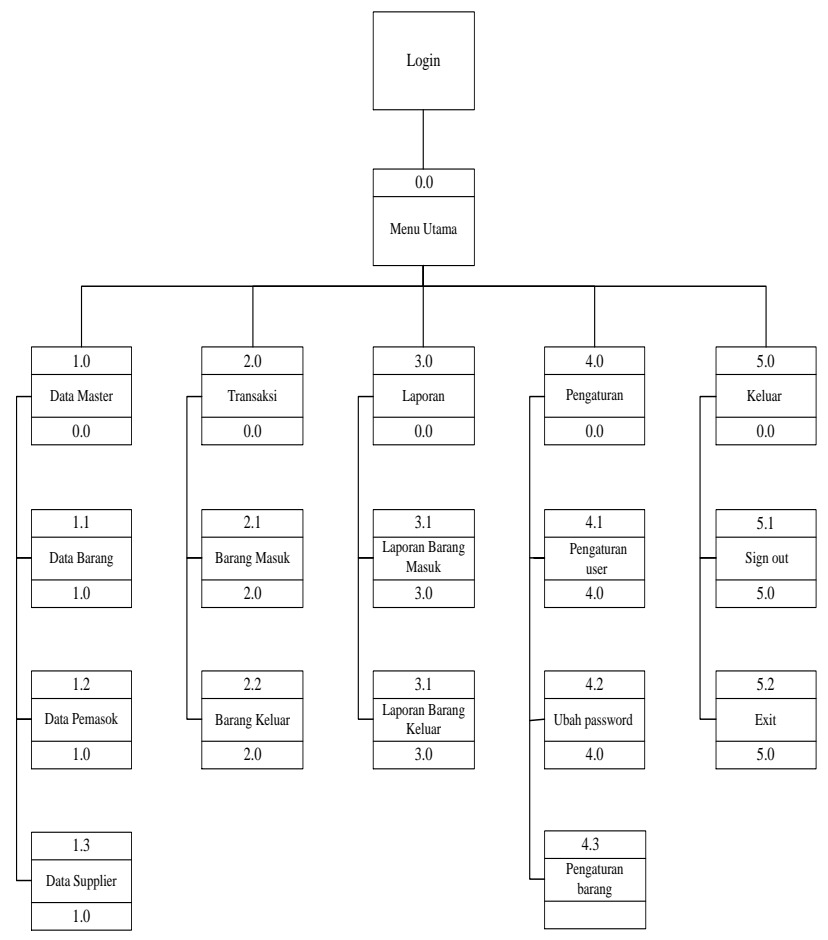

Gbr 4. Diagram HIPO (Hierarchy plus Input Process Output)

Pada Gbr 4 tersebut adalah gambaran mengenai hierarchy program yang dibuat. Dalam program tersebut, untuk dapat melakukan akses terhadap program, maka harus melakukan proses login terlebih dahulu, apabila berhasil, maka pengguna dapat mengakses semua meni di dalamnya.

\section{4) Spesifikasi Sistem Komputer}

Untuk memperoleh kemampuan yang optimal dalam pengolahan data diperlukan aspek dasar yaitu perangkat keras (Hardware) dan perangkat lunak (Software) yang saling berkaitan satu dengan lainnya karena suatu sistem komputerisasi tidak akan berjalan tanpa ada salah satu aspek tersebut. Perangkat lunak dan perangkat keras harus dapat menunjukan kerja yang baik dan sesuai dengan yang diharapkan. Perangkat keras (hardware) merupakan serangkaian unsur-unsur yang terdiri dari beberapa perangkat keras yang membentuk suatu sistem komputer yang digunakan untuk mengoperasikan proses kerja pemakai.

Spesifikasi perangkat keras yang digunakan adalah Monitor: 14", Proccessor: Core2 Duo @ 2,00 GHz or Higher, Memory: 1 GB (Minimum), Harddisk: 80 GB, Keyboard: 102 Keys USB atau PS/2, Printer: Ink Jet, Mouse: Optical Mouse $U S B$ atau $P S / 2$. 
Bagian penting lain yang mendukung program adalah perangkat lunak (software) yang digunakan dalam mengeksekusi program aplikasi serta sistem operasi yang akan digunakan untuk menjalankan program tersebut. Sistem operasi ini berfungsi untuk mengidentifikasi dan menyiapkan aplikasi program sehingga tata kerja seluruh peralatan komputer dapat terkontrol. Perangkat lunak yang dibutuhkan untuk menjalankan aplikasi program persediaan bahan baku dan pendukung ini adalah Sistem operasi: Windows 7 x86 or Higher, Bahasa pemrograman: Visual Basic 6.0, Program atau software pendukung: Xampp and Crystal Report.

\section{5) Flowchart}

Penggambaran secara grafik dari langkah-langkah dan urutan-urutan prosedur dari suatu program.

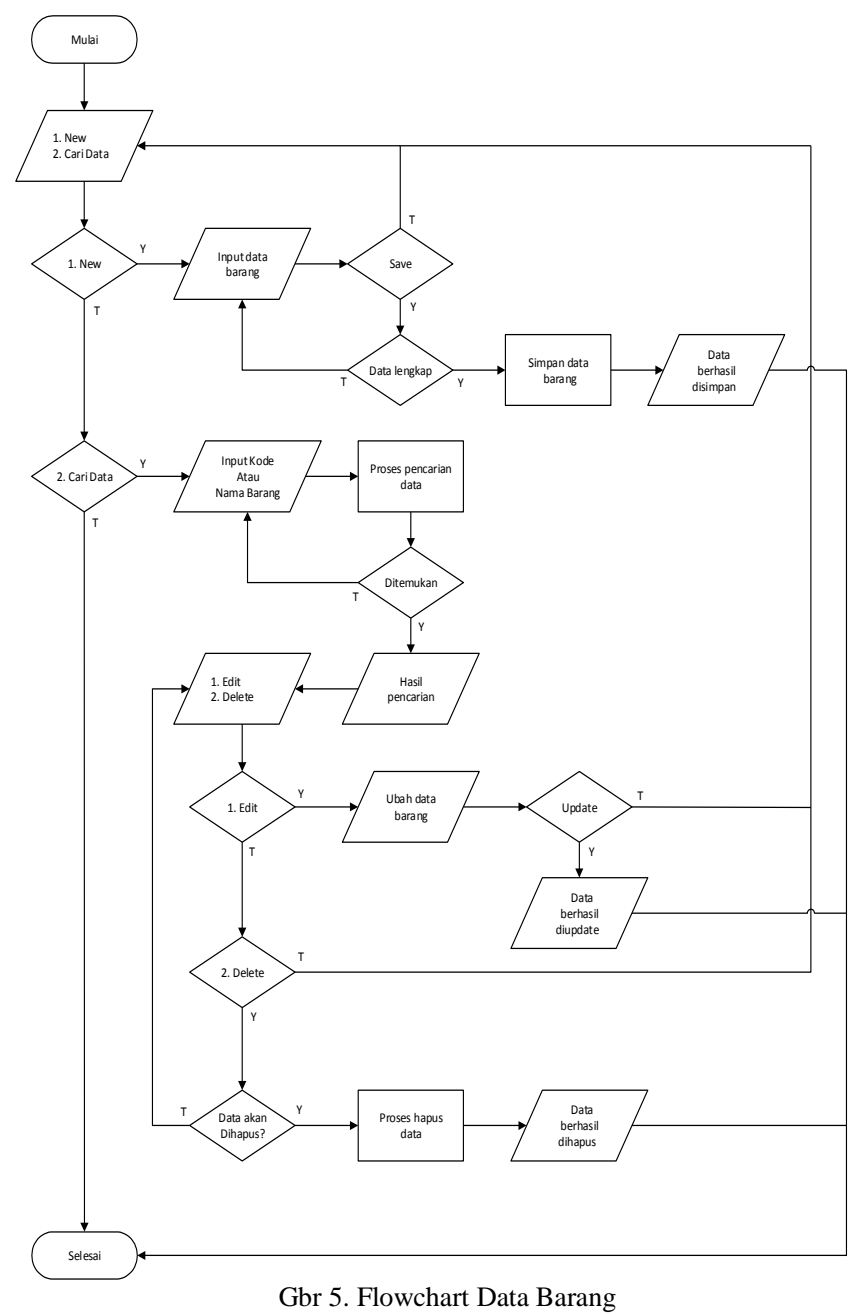

Gbr 5 adalah gambaran arus prosedur program pada data barang, pada data barang tersebut, terdapat dua pilihan yakni menambah baru atau mencari data, jika memilih menambah baru, maka pengguna dapat melakukan penambahan data barang. Jika memelilih pencarian, pengguna dapat melakukan pengubahan data atau penghapusan data barang.

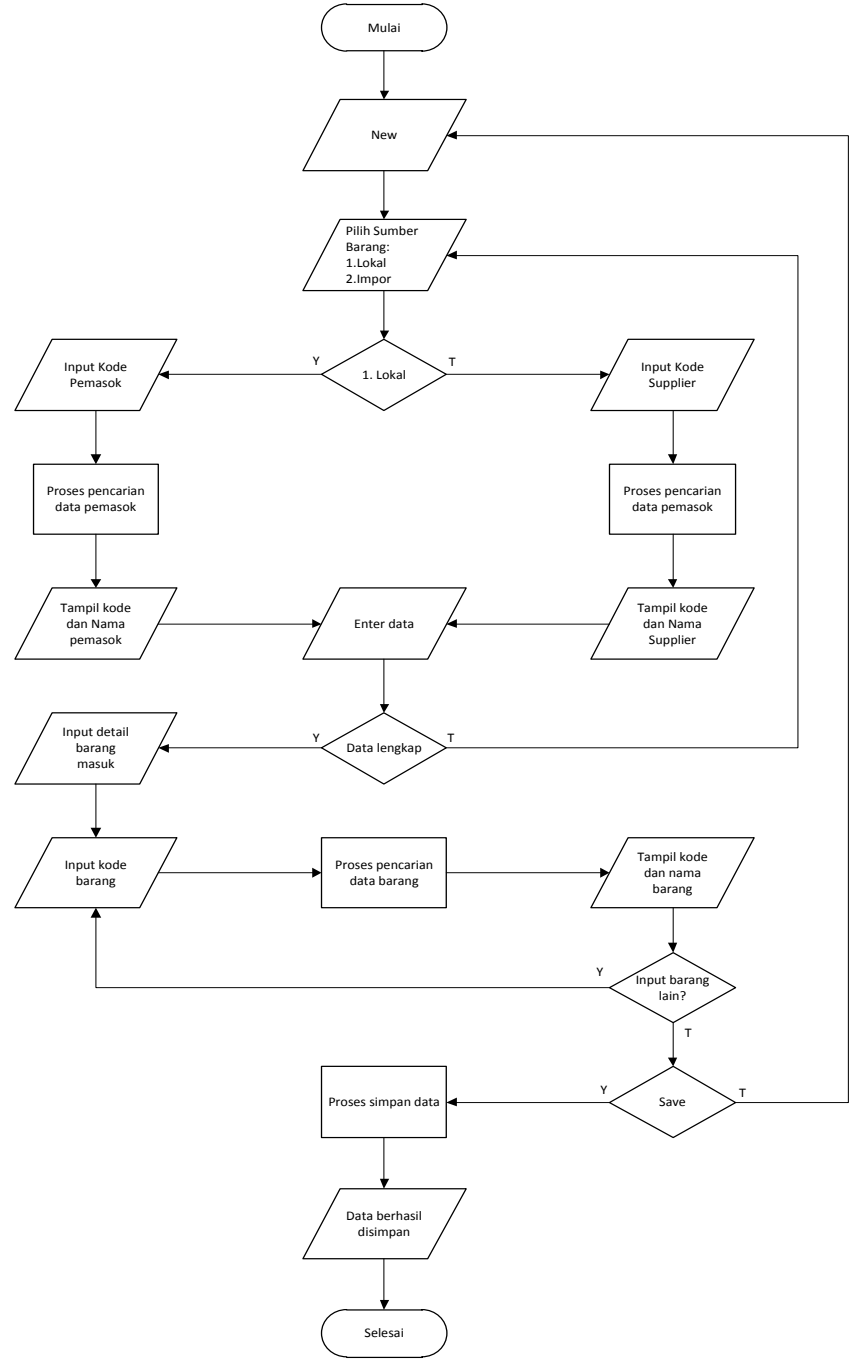

Gbr 6. Flowchart Transaksi Barang Masuk

Gbr 6 menjelaskan mengenai prosedur program saat terjadi transaksi barang masuk. Jika terjadi transaksi barang masuk, maka pengguna harus melihat terlebih dahulu sumber barang tersebut berasal dari local atau import. Setelah itu maka lakukan penambahan data, setelah proses penyimpanan data barang masuk, pengguna juga dapat melakukan pencarian data yang pernah ditambahkan sebelumnya untuk melakukan pengecekan bukti transaksi barang yang pernah masuk ke gudang. 


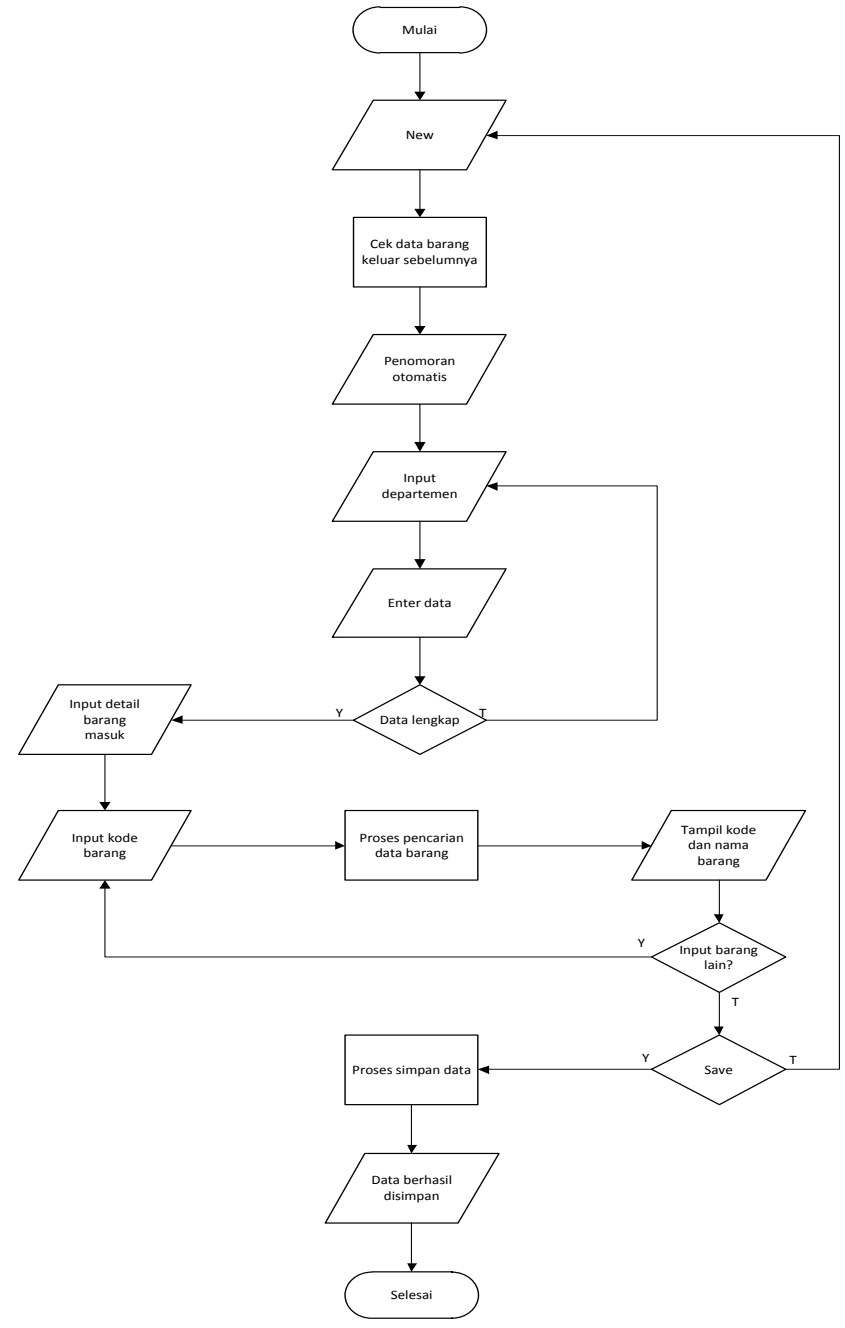

Gbr 7. Flowchart Transaksi Barang Keluar

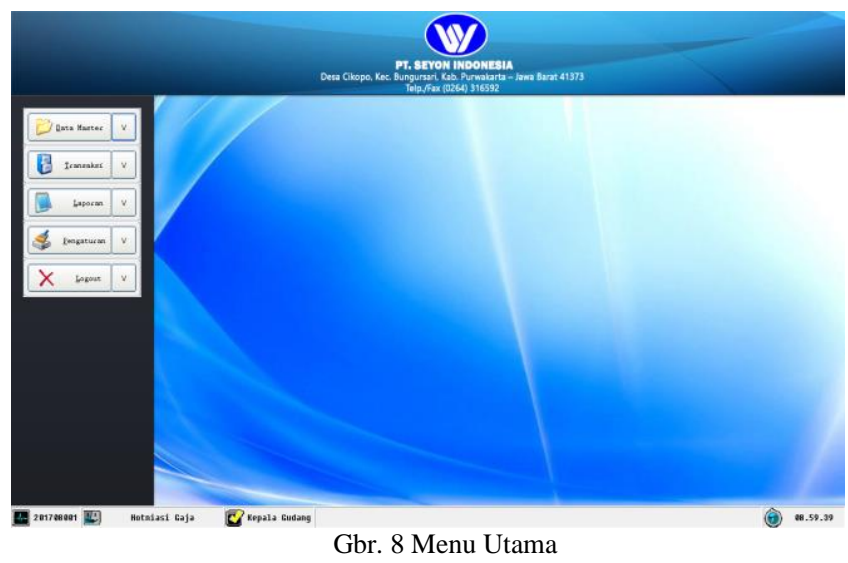

\section{Implementasi}

Hasil dari bagian implementasi program persediaan bahan baku dan pendukung. Impelementasi interface diperlihatkan Gbr.8, Gbr.9, Gbr.10, Gbr.11, Gbr.12, Gbr.13, dan Gbr.14.
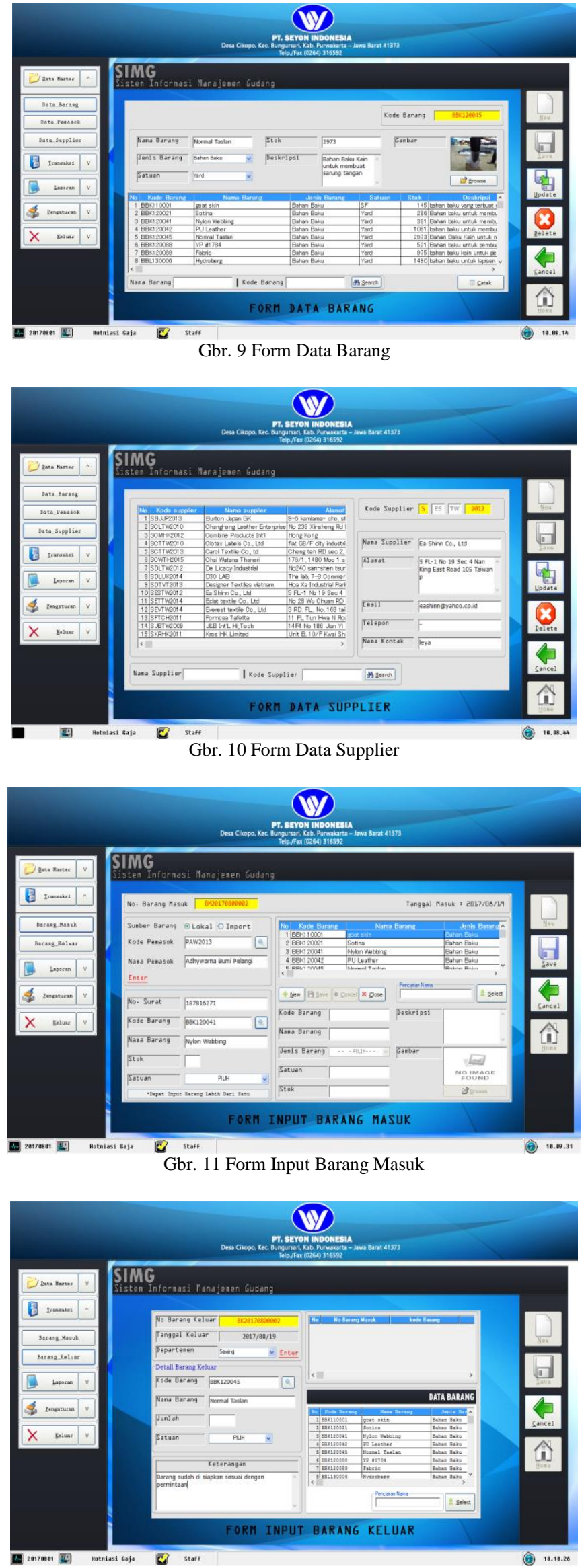

Gbr. 12 Form Input Barang Keluar 

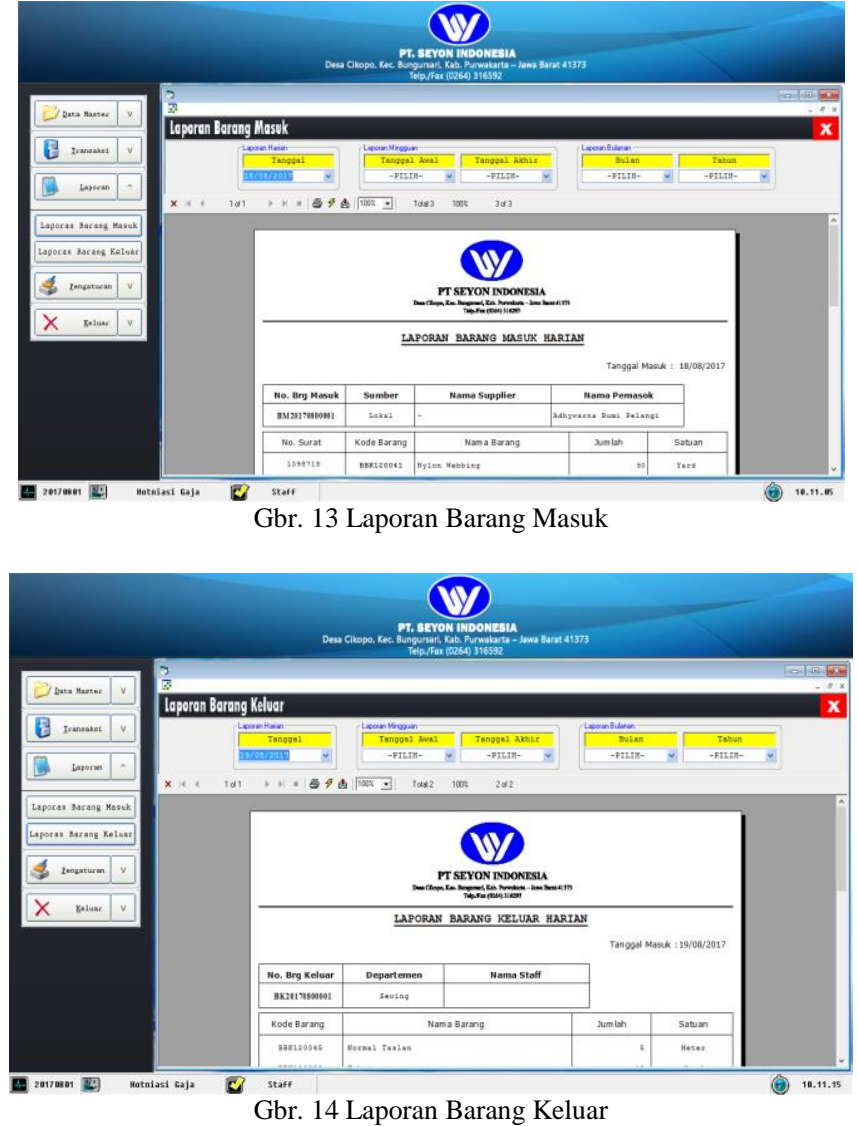

\section{E. Pengujian Integrasi dan pengujian sistem}

Pengujian integrasi adalah teknik untuk mengkontruksi struktur pogram dengan melakukan pengujian untuk mengungkap kesalahan sehubungan dengan menggabungkan modul-modul secara bersama-sama. Integrasi dilakukan dengan pendekatan top-down terhadap struktur program. Modul diintegrasikan dengan menggerakkan ke bawah melalui hirarki kontrol yang dimulai dari modul menu utama.

Pengujian sistem merupakan elemen kritis dari jaminan kualitas perangkat lunak dan merepresentasikan kajian pokok dari spesifikasi, desain dan pengkodean. Dalam penelitian ini rancangan pengujian sistem dilakukan dengan melakukan pengujian black-box terhadap semua fungsi dalam aplikasi. Pengujian black-box merupakan salah satu pengujian aplikasi atau perangkat lunak yang berfokus pada persyaratan fungsional perangkat lunak. Karena itu uji coba black-box memungkinkan pengembang software untuk membuat himpunan kondisi input yang akan melatih seluruh syaratsyarat fungsional suatu program [15].

Pengujian dilakukan pada program yang telah selesai dirancang untuk menyesuaikan dengan kebutuhan pengguna. Berikut Tabel 1. Hasil Pengujian BlackBox Testing pada form login.

TABEL I

Hasil PENGUJian BLACK Box PADA Form Login

\begin{tabular}{|c|c|c|c|c|c|}
\hline No & Skenario Pengujian & Test Case & $\begin{array}{c}\text { Hasil yang } \\
\text { diharapkan }\end{array}$ & $\begin{array}{c}\text { Hasil } \\
\text { Pengujian }\end{array}$ & Kesimpulan \\
\hline 1 & $\begin{array}{l}\text { Nama user dan Password } \\
\text { tidak diisi kemudian klik } \\
\text { tombol login }\end{array}$ & $\begin{array}{l}\text { Nama user: (kosong) } \\
\text { Password: (kosong) }\end{array}$ & $\begin{array}{l}\text { Sistem akan } \\
\text { menolak akses }\end{array}$ & $\begin{array}{l}\text { Sesuai } \\
\text { harapan }\end{array}$ & Valid \\
\hline 2 & $\begin{array}{l}\text { Mengetikkan Nama user dan } \\
\text { Password tidak diisi atau } \\
\text { kosong kemudian klik } \\
\text { tombol login }\end{array}$ & $\begin{array}{l}\text { Nama user: } \\
\text { wasiyanti } \\
\text { Password: (kosong) }\end{array}$ & $\begin{array}{l}\text { Sistem akan } \\
\text { menolak akses }\end{array}$ & $\begin{array}{l}\text { Sesuai } \\
\text { harapan }\end{array}$ & Valid \\
\hline 3 & $\begin{array}{l}\text { Nama user tidak di isi } \\
\text { (kosong) dan Password diisi } \\
\text { kemudian klik tombol login }\end{array}$ & $\begin{array}{l}\text { Nama user: (kosong) } \\
\text { Password: admin }\end{array}$ & $\begin{array}{ll}\text { Sistem } & \text { akan } \\
\text { menolak } & \end{array}$ & $\begin{array}{l}\text { Sesuai } \\
\text { harapan }\end{array}$ & Valid \\
\hline 4 & $\begin{array}{l}\text { Mengetikkan } \\
\text { salah satu kondisi salah pada } \\
\text { Nama user atau Password } \\
\text { kemudian klik tombol login }\end{array}$ & $\begin{array}{l}\text { Nama user: wasiyanti } \\
\text { (benar) } \\
\text { Password: } \\
12345 \text { (salah) }\end{array}$ & $\begin{array}{l}\text { Sistem akan } \\
\text { menolak } \\
\text { akses akan kembali } \\
\text { diarahkan ke } \\
\text { halaman login } \\
\text { dan menampilkan } \\
\text { pesan "Maaf, Email } \\
\text { dan Password Anda } \\
\text { Salah!!" }\end{array}$ & $\begin{array}{l}\text { Sesuai } \\
\text { harapan }\end{array}$ & Valid \\
\hline 5 & $\begin{array}{l}\text { Mengetikkan Nama user dan } \\
\text { Password dengan data yang } \\
\text { benar kemudian klik tombol } \\
\text { login }\end{array}$ & $\begin{array}{l}\text { Nama user : wasiyanti } \\
\text { (benar) } \\
\text { Password: } \\
\text { Admin (benar) }\end{array}$ & $\begin{array}{lr}\text { Sistem akan } \\
\text { menerima akses } \\
\text { login dan akan } \\
\text { menampilkan pesan } \\
\text { "Login Berhasil! "“ }\end{array}$ & $\begin{array}{l}\text { Sesuai } \\
\text { harapan }\end{array}$ & Valid \\
\hline
\end{tabular}




\section{KESIMPULAN}

Pelayanan dan penyajian informasi yang cepat, tepat dan akurat sangat penting bagi perkembangan suatu organisasi atau lembaga. Searah dengan perkembangan ilmu pengetahuan dan teknologi dengan munculnya sistem pengolahan data dengan menggunakan komputer sangat membantu sekali dalam mendapatkan informasi yang cepat, tepat dan akurat. Berdasarkan hasil riset yang dilakukan oleh penulis dengan mengamati dan menganalisa sistem berjalan dan pengolahan data yang digunakan pada gudang PT Seyon Indonesia bahwa perlu diterapkan sistem yang terkomputerisasi dengan merancang sebuah program yang dapat membantu mengelola data lebih efektif dan efisien. Yang mana nantinya dapat menggantikan sistem lama yang masih manual.

Maka dapat diambil kesimpulan yaitu adanya proses komputerisasi memberikan suatu keuntungan yang sangat mendasar bagi perusahaan yaitu berupa otomatisasi dan peningkatan kualitas informasi. Dalam sistem pengelolaan data pada gudang ternyata banyak ditemui kelemahan-kelemahan seperti yang penulis uraikan pada analisa kebutuhan dimana proses dalam pengelolaan data tidak berjalan secara maksimal, tetapi dengan perancangan aplikasi yang dibuat ini diharapkan dapat mengatasi hal tersebut. Dalam pembuatan laporan data barang masuk dan keluar serta untuk melihat stok barang terupdate yang penulis rancang ini berpedoman pada laporan data barang masuk dan keluar yang ada pada PT Seyon Indonesia saat ini. Dimana laporan data barang masuk dan keluar serta penghitungan stok barang sebelumnya masih dikelola secara manual. Maka dengan aplikasi dekstop ini semua permasalahan tersebut akan dapat teratasi.

Adapun saran-saran yang disampaikan berdasarkan hasil dari perancangan dan pembuatan program ini adalah Setelah program benar-benar diterapkan diperlukan adanya pemeliharaan dan perawatan secara rutin terhadap perangkat keras maupun perangkat lunak demi kelancaran dalam proses pengolahan data. Pada periode tertentu perlu adanya pengecekan kembali dan pembaharuan program yang diusulkan guna menjaga dan meningkatkan kualitas program tersebut.

\section{DAFTAR PUSTAKA}

[1] Anhar., "Panduan Menguasai PHP dan MYSQL Secara Otodidak." Jakarta Selatan: Media Kita. 2010.

[2] Brady, M \& Loonam., J. "Exploring The Use Of Entity-Relationship Diagramming As a Technique To Support Grounded Theory Inquiry." Bradford: Emerald Group Publishing. 2010.

[3] Enterprise, Jubilee., "Mengenal Pemrograman Database." Jakarta: Elex MediaKomputindo. 2015

[4] Fathansyah., "Basis Data." Bandung: Informatika. 2007

[5] Jogiyanto. "Analisis \& Desain (Sistem Informasi: Pendekatan Terstruktur Teori dan Praktik Aplikasi Bisnis." Yogyakarta: CV Andi Offset. 2014.

[6] Komputer, Wahana., "Membangun Aplikasi Database dengan Visual Basic 2012”. Semarang: CV Andi Offset. 2012.

[7] Kusbianto, Dedi. "Analisa dan Perancangan Sistem Informasi "Bangil: TMIK Yudika. 2010.

[8] Kustiyahningsih, Yeni., "Pemrograman Basis Data Berbasis Webmenggunakan PHP dan MYSQL”. Jakarta: Graha Ilmu. 2011.

[9] Raharjo, Budi, Imam Heryanto dan Enjang R. K., 2010. Modul Pemrograman Web (HTML, PHP \& MYSQL). Bandung: Modula

[10] Reza, A \& Magdalena, K. "Aplikasi Untuk Optimasi Persediaan Bahan Baku Menggunakan Model Economic Order Quantity (eoq) Pada Pabrik Tahu Di Jawa Barat." Seminar Nasional Teknologi Informasi dan Multimedia 2016, ISSN: 2302-3805. 2016.

[11] Rianti, R, Anak Agung, \& FitriSukmawati. "Aplikasi Perhitungan Persediaan Bahan Baku dengan Metode Economic Order Quantity Berdasarkan Varian Produk (Studi Kasus: CV Dwi Sumber, Semarang)". Jurnal Nasional Pendidikan Teknik Informatika, 5(1). ISSN 2087-2658. 2016.

[12] Rosa A.S. dan M. Shalahuddin., Rekayasa Perangkat Lunak. Bandung: Informatika. 2013.

[13] Sutabri, Tata., "Struktur Navigasi dan Basis Data." Jakarta: Elex Media Komputindo. 2012

[14] Yudhi Yanuar, Raswyshnoe, B.K, \& Julia, E.M. "Web untuk Pengelolaan Bahan Baku Produksi Menggunakan Metode Economic Order Quantity". e-Proceeding of Applied Science, ISSN: 2442-5826 2016.

[15] Sasmito, Ginanjar "Penerapan Metode Waterfall Pada Desain Sistem Informasi Geografis Industri Kabupaten Tegal". Jurnal Pengembangan IT (JPIT). Vol. 2 Nomor, Januari 2017. e-ISSN: 25489356. 